\title{
Investigations of the Plum pox virus in Chile in the past 20 years
}

\author{
Guido Herrera ${ }^{1}$
}

Sharka disease, which is caused by Plum pox virus (PPV), is one of the most serious diseases affecting stone fruit trees around the world. Identified in Bulgaria in 1931, it was restricted to the European continent until 1992 when the virus was identified in Chile. It was subsequently verified in the USA, Canada, and Argentina. After 20 years since first detecting PPV in Chile, it seems clear that the disease cannot be eradicated in spite of various measures. Considering the seriousness of this problem for the domestic industry, a series of studies have been conducted to determine the distribution and degree of transmission of the disease, its biological and molecular characterization and epidemiological aspects, etc. The available information has allowed national phytosanitary control agencies to take steps to decrease the effects of the virus. However, there is a lack of data with respect to epidemiological factors for a more accurate understanding of the performance of the virus under Chilean conditions.

Key words: Sharka disease, virus, stone fruit.

\section{INTRODUCTION}

The first symptoms of Sharka or Pox were observed by farmers in southwest Bulgaria after the First World War and the first scientist to describe the viral nature of the disease was Dimitar Atanasov in 1933 (Dzhuvinov et al., 2007), calling it Sharka disease or Plum pox virus (PPV). Since then, PPV has become one of the most serious problems for the stone fruit industry in Europe (Németh, 1986). Since the appearance of the first symptoms in apricots (Prunus armeniaca L.) in 1926, studies in different countries affected by this serious disease have revealed its causal agent, its characteristics, different isolates, means of transmission and relevant information with regard to the behavior of different stone fruit cultivars. The most important landmarks include transmission by grafting buds in 1931, demonstrating the viral nature of the disease (Atanosoff, 1932). In 1937, the causal agent of Sharka symptoms was identified and the plum was determined to be the best indicator of the presence of the virus (Prunus salicina L.) cv. Myrobalan (Christov, 1944). In the mid-1960s, the range of herbaceous and woody hosts was determined (Trifonov, 1965). Diagnosis was significantly advanced in the 1970s and 1980s with serological techniques like micro precipitation and later the ELISA test. At the end of this period and beginning of the 1990s, PPV was detected by ELISA in apricot, peach (Prunus persica L.), and cherry (Prunus avium L.) (Topchiika, 1992). Later, it was possible to use much

${ }^{1}$ Instituto de Investigaciones Agropecuarias INIA, Casilla 439, Correo 3, Santiago, Chile. Corresponding author (gherrera@inia.cl).

Received: 02 October 2012.

Accepted: 10 January 2013. more precise diagnosis techniques like Polymerase Chain Reaction (PCR) (Wetzel et al., 1991; Hadidi and Levy, 1994), resulting in greater knowledge about the range of hosts and viral strains. As well, biotechnological methods associated with genetic transformation generated plant varieties with characteristics of immunity to the virus (Malinowski et al., 2006).

The presence of the virus in the Americas was verified for the first time in Chile in 1992 (Herrera, 1994; Herrera et al., 1997) and it was found to have spread to all areas growing stone fruit (Herrera et al., 1998; Herrera and Madariaga, 2002; 2003; Muñoz and Collao, 2006). The virus was detected in 1999 in Adams County,Pennsylvania, USA. Quarantine measures were quickly taken to prevent the spread of the disease (Dunkle, 1999). However, there were subsequent reports of positive samples in New York and Michigan (Barba et al., 2011). Subsequently, PPV was detected in Canada in 2000 (Thompson et al., 2001) and in Argentina in 2006 (Dal Zoto et al., 2006). While the disease had been limited to Europe for many years, in addition to the Americas it has been detected in Asian countries such as China, Pakistan, India, and Japan (Barba et al., 2011).

PPV belongs to the genus Potyvirus, of the potyviridae family. The genome consists of one positive molecule, single-stranded RNA encapsulated in filamentous viral particles, about $750 \mathrm{~nm}$ long and $15 \mathrm{~nm}$ wide. The virus is transmitted from infected trees by grafting and other vegetative propagation techniques or non-persistently by aphid vectors such as Aphis spiraecola and Myzus persicae. The numerous PPV isolates differ in biological and epidemiological properties such as aggressiveness, aphid transmissibility, and symptomatology. These differences have been serologically and molecularly documented, 
leading to the clustering of PPV into six types or strains; PPV-D, PPV-M, PPV-EA, PPV-C, PPV-W and PPV-rec (Candresse and Cambra, 2006). The costs associated with the disease involve not only direct losses in stone fruit production, eradication, compensatory measures, and lost revenue, but also indirect costs including those from preventive measures such as quarantine, surveys, inspections, control nurseries, diagnostics, and the impact on foreign and domestic trade (Cambra et al., 2006).

The main causes of PPV spreading throughout the world are illegal trafficking and inefficient virus control in propagation material exchanged among countries. Once the virus is established in an area, the aphid vector species spread it within the same area and later winged forms of these vectors transmit it to neighboring Prunus species. The presence of the disease in a country or specific geographic area has serious agronomic, economic, and policy consequences. Productivity is mainly affected by reduced fruit quality and trees falling prematurely. In addition, its characteristic of being transmitted by aphid vectors and propagation material makes it difficult to control. The PPV does not kill the plant, but if infected plants are not removed, they will serve as inocula to spread the virus to healthy plants. Technical and policy decisions for eradication programs must be supported by quantitative data, hence the importance of knowing the epidemiology of the virus, behavior of host species, and the most affected geographic areas. It is necessary then to establish special regulations and develop specific control strategies to maintain disease-free nurseries. In this sense, the relationship among state agencies responsible for regulations and the nursery operators is essential for virus control. This work, 20 years since the virus was detected in Chile, aims to summarize existing knowledge and envision future research tasks in order to contribute specific criteria for PPV control in our stone fruit industry.

\section{Detection and strain characterization}

During the 1991-1992 growing season, symptoms similar to those caused by PPV were observed in an old stone fruit collection located at Buin (Metropolitan Region), Chile (Herrera, 1994). Apricot plants cv. Bergeron showed chlorotic rings in their leaves, malformation of fruit, with typical rings produced by PPV. Fruit seeds from the affected plants showed typical yellow rings on the surface, while peach plants cv. Springcrest showed chlorosis in new leaves around secondary veins. The presence of characteristic PPV symptoms in apricot and peach, positive reaction to poly- and monoclonal antiserum, observation of particle type potyvirus with specific antisera of the virus under electron microscope confirmed the presence of the virus with a high degree of confidence (Herrera, 1994; 1997; 2000a; 2001). This data, published in 1994, was the first reference to the presence of this virus in the Americas (Herrera, 1994). Until then PPV had been restricted to Europe. The identification of the virus was reported to the international community at the Conference on Plum pox virus in Bordeaux, France, in 1993 (Acuña, 1993). At the same time, national authorities through the Agricultural and Livestock Service (SAG) established compulsory testing for the virus throughout the country (SAG, 1994).

The identification of PPV in Chile was later corroborated by PCR (Rosales et al., 1996), from the viral RNA present in crude extracts of affected plants. The authors prepared cDNA from the extreme 3' terminal region of the virus genome, which served as a template in PCR, in which two pairs of primers were used, one amplifying a $243 \mathrm{bp}$ (base pairs) fragment of the terminal carboxyl region of the cover protein of the viral gene (Wetzel et al., 1991), and a 220 bp fragment in the 3 ' non-coding region of the PPV genome (Hadidi and Levy, 1994). These fragments of DNA amplification allowed the specific identification of the virus in 24 of 28 analyzed samples.

Later, in order to determine the PPV strain of the isolate detected in Chile, Rosales et al. (1996; 1998) cloned and sequenced 243 bp fragments (Wetzel et al., 1991) using extracts from plant leaves with PPV symptoms collected in different localities in Chile. The nucleotide sequence of the cloned fragments showed the presence of restriction sites of the enzyme Rsal (GTAC), which is characteristic of PPV-D strain. The same fragments contained sites preserved in recognition of the Alu1 enzyme, found in the majority of PPV isolates. Comparing the nucleotide sequences of the amplified fragments to other PPV sequences revealed a very similar homology to PPV-D. The identity varied from approximately $92.6 \%$ to $99.2 \%$. The highest percentages of homology were found with those known as typical of PPV-D (PPV-Ranković, PPV-D, PPV-NAT) and the lowest (92.6\%) with PPV-El Amar (Cervera et al., 1993).

Reyes and others (Reyes etal.,2001;2003) characterized eight Chilean isolates based on biological and molecular methods. The isolates were transmitted by grafting to Prunus tomentosa Thunb. and by mechanical inoculation to Nicotiana benthamiana Domin. The Chilean isolates did not show symptomatological differences from PPV-D in those species. On the other hand, from the molecular point of view, the authors concluded that the eight isolates from different geographic areas of the country included in routine PPV checks, correspond to the PPV-D strain based on comparing the nucleotide sequence of the isolates to those belonging to the D, M, C, and El Amar PPV strains. However, when they compared the sequence of the Chilean isolates within the branch of the virus D strain, they determined that three were closely related to isolates described in central Germany (Deborré et al., 1995), another three showed high homology to isolates described in Poland (Malinowski et al., 2006) and one French isolate (Ravelonandro et al., 1988). This suggests that the Chilean PPV isolates originate from more than one place. Based on the available information and the 
view that the studied isolates are representative of the virus in Chile, the authors concluded that the only strain of the virus present in the country is PPV-D. Fiore et al. (2010) concluded the same after analyzing 14 isolates from different localities and comparing them to PPV-D type with PCR. This information has allowed SAG to officially report that the only strain of PPV in the country is the D type (Muñoz and Collao, 2006).

However, specific isolates have been identified that do not necessarily respond in their molecular behavior to the PPV-D type. Numerous cases have been found under field conditions with no obvious symptoms of PPV, but samples from these plants are positive to specific commercial antiserum of PPV (Herrera et al., 1998), and positive to specific primers to the 3' end region of the viral genome (Reyes et al., 2001). Reyes et al. (2001), working with asymptomatic isolates from peach trees transmitted to Nicotiana clevelandii A. Gray and $N$. benthamiana, indicated that unlike the samples from symptomatic isolations, these isolates have a weak reaction to commercial antiserum BIOREBA (Reinach, Switzerland). As well, when using different primers (forward) as complementary to those used to amplify the region corresponding to the coat protein $(\mathrm{CP})$ of viral genome, the forward PPV9115 and PPV9207 give a faint signal. This contrasts with the results of symptomatic peach samples where the amplification of cDNA yields the expected fragments in all cases. These authors concluded that the results suggest important differences between Potyvirus (symptomatic and asymptomatic), partially explaining the different reactions to the commercial BIOREBA antiserum. For years PPV was considered to have a highly conserved nucleotide sequence since the first isolates had a high level of similarity. However, the sequence and characterization of other isolates in recent years reveal a wide range as a product of viral recombination (Cervera et al., 1993).

\section{Distribution and dissemination}

There are 8545 ha of almond (Prunus dulcis (Mill.) D.A. Webb), 13174 ha of cherry, 21001 ha of plum, 1405 ha of apricots and 13885 ha of peach in Chile, representing $20.8 \%$ of the total area cultivated with fruit trees (ODEPA, 2012). Chile has an expectant position among exporters of stone fruits in the southern hemisphere, making it necessary for the industry, have a special concern for all those factors that mean losses in quality and fruit production. Among these factors are diseases caused by virus and associated for which there are no methods to remove it from the plants. Numerous viruses have been reported globally that affect these fruit tree species (Németh, 1986). The following viruses affecting stone fruit have been identified in Chile; Prunus necrotic ringspot virus (PNRSV) (Ascui and Alvarez, 1988), Prune dwarf virus (PDV) (Herrera, 1996; Herrera and Madariaga, 2002), Tomato ringspot virus (TomRSV)
(Auger, 1989) and Plum pox virus (Herrera, 1994). A first approximation of the incidence of these viruses in Chile was reported in 2002, finding a predominance of PNRSV and PDV (20\% to $30 \%)$ over TomRSV (5\%) (Herrera and Madariaga, 2002).

In 1998, Herrera et al. (1998) did the first study of the incidence of PPV in commercial stone fruit orchards in Chile. They employed the ELISA method to detect the virus and collected samples at random from orchards (50 samples per orchards) for three growing seasons (1994-1995, 1995-1996, and 1996-1997. The authors established the distribution and incidence of the virus in the country. Prior to this work, PPV had only been determined in specific areas near Santiago (Herrera, 1994). It was concluded that the virus was not affecting a particular area but rather was widely distributed wherever stone fruit production was taking place in Chile. From a total of 10051 samples collected in the three growth seasons, 15.2 were positive for PPV, Infection rates averaged over the three years were $13.1^{\circ} \%$ in Atacama Region, $18.5 \%$ in Coquimbo Region, $11.9 \%$ in Valparaíso Region, $15.7 \%$ in the Metropolitan Region, and $16.4 \%$ in O'Higgins Region. The most affected species were peach $(15.3 \%)$ and nectarin $(17.2 \%)$, followed by plum $(8.3 \%)$, with minor infection detected in apricot $(1.9 \%)$. In 2007, a PPV survey of commercial orchards based on 1396 collected samples (three samples per orchard) and analyzed by immuno-impression in the area where the fruit were cultivated, reported that $3.2 \%$ of the samples were positive for PPV-D (Fiore et al., 2010).

In this extensive work (Herrera et al., 1998) some factors from the epidemiological point of view seem to be relevant and it is necessary to highlight that the methodology included sufficient random samples from every orchard and that the total of samples was more than 10000 . First, the disease was found distributed everywhere that stone fruit is grown in Chile. This suggests that there are sufficient sources of inoculum for the virus to continue spreading from orchard to orchard using aphids as a vector. Second, the obvious PPV symptoms in leaves and fruits were observed only in the Metropolitan and Libertador General Bernardo O'Higgins Regions. In other regions PPV-positive plants were asymptomatic. This contrasts with the European experience where the virus, once established in an area, spreads quickly in the following four seasons and between $60 \%$ and $90 \%$ of plants show symptoms. The difference may be associated with higher spring temperatures in Europe, which decreases viral concentrations in affected plants and preventing severe symptoms. It also cannot be ruled out that Chilean plant varieties, being mainly American in origin could have different reactions to viral infection from those of plants commonly used in Europe. Third, the highest percentages of infection were found in peach and nectarine rather than plum and apricot. This is consistent with descriptions of PPV-D behavior in Europe where aphid vectors easily 
transmit easily the virus to peach and nectarine, while it is more difficult to move from these species to plum and apricot (Barba et al., 2011).

Infection rates in nurseries are lower than those in commercial orchards. Thus, the work carried out in 2000 (Herrera, 2000a; 2000b; Herrera and Madariaga, 2002) on a total of 13609 nursery plants analyzed by ELISA showed an average PPV-D infection rate in six species (peach, nectarine, plum, apricot, almond, and cherry) of $4.2 \%$. The virus was found in almond $(2.6 \%)$, plum $(7.7 \%)$, apricots $(35.3 \%)$, peach $(2.6 \%)$ and nectarine (7.7\%). In 2006 (Muñoz and Collao, 2006), SAG showed results of mandatory disease control in stone fruit tree nurseries, which considered a total of 158403 samples tested by DASI-Elisa and PCR over $10 \mathrm{yr}$ and found $0.11 \%$ of plants PPV-D. In general, comparing the results of studies in the 1990s to those of more recent studies, the percentages of PPV in stone fruit (from orchards and nurseries) have been decreasing. This could be partly attributed to compulsory SAG to prevent the virus from spreading by monitoring for PPV in nursery and orchard stone fruit.

\section{Epidemiology}

Since PPV was identified in Chile in 1994 (Herrera, 1994) studies have been conducted on its impact on commercial stone fruit orchards (Herrera et al., 1998; Fiore et al., 2010) and nurseries (Muñoz, 2001; Herrera and Madariaga, 2002), as wells as on prevalent strains (Rosales et al., 1998) and molecular characteristics (Reyes et al., 2001). However, there is not enough information on epidemiological aspects to allow for making decisions or establishing criteria with respect to the evolution of the disease in specific areas in Chile. In 2003, Herrera and Madariaga (2003) evaluated the degree of virus spreading in a commercial apricot orchard with three cultivars: 'Dina', 'Castelbrite', and 'Katy'. Results showed that the number of 'Dina' plants with PPV symptoms in fruits increased $26.7 \%$ in a period of $4 \mathrm{yr}$, but in the last season a further $24.2 \%$ of the plants were ELISA-positive, although they showed no symptoms. In such this case, plants with symptoms and those in the latency period of the virus increased by $50.9 \%$ in a period of $4 \mathrm{yr}$. The spread of the virus was significantly less in 'Castelbrite' and 'Katy' than in 'Dina'. The speed at which the virus spread in this study was less than in cases in Spain (Llacer et al., 1992), where it required between 2 and $5 \mathrm{yr}$ to reach $100 \%$. A study in France described periods of 8 to $9 \mathrm{yr}$ to reach $100 \%$ infection (Adamolle et al., 1994). The results of this work suggest that all the factors for virus spreading in field are present. In fact, the aphid species Myzus persicae, Aphis craccivora, and A. gossyppi were identified as the most abundant among stone fruit and as transmitters of PPV (Muñoz and Collao, 2006). The speed of viral spread depends on the transmission efficiency of the most abundant aphid species in a given place, production of winged forms, winds in the area, and the presence of inoculum sources (weeds and susceptible cultivar).

In epidemiological terms, not only population dynamics of vectors play an important role, but also the degree of susceptibility of commercial varieties. Cultivars that are more susceptible to the virus or those that show more severe symptoms or have a shorter incubation period have higher concentrations of the virus. Consequently, varietal behavior will be a determining factor that will affect the greater or lesser spread of the virus through an orchard and/or area. There have been no specific studies in Chile of the response of different commercial varieties to viral infection under field conditions. However, studies of peach and apricot have shown that under our conditions, the virus has distinct effects on different varieties. For example, the peach cultivar 'Mary Gene Tree' showed higher rates of infection than 'Suncrest' (Millán, 1995), while in apricot, 'Dina' is much more susceptible than 'Katy' and 'Castelbrite' (Herrera and Madariaga, 2003). From this perspective, it is necessary carry out much more research on the reaction of Chilean stone fruit cultivars to PPV in order to recommend best material to the producers.

\section{Control}

PPV is the most important disease affecting the stone fruit sector mainly because it can severely reduce fruit quality and consequently reduce exports. It also has a strong capacity to spread under field conditions, covering extensive crop areas. Consequently this pathogen is considered in Europe and the USA as one of the greatest threats to the stone fruit industry (Barba et al., 2011). To prevent the introduction of the virus, countries have implemented regulatory systems for the exchange of plant material. However, when the disease is detected for the first time in a given area, it is necessary to take drastic measures to apply control through eradication schemes. If these are not effective, authorities must establish measures to contain the disease to reduce damage and prevent its spreading to areas free of the virus. From this perspective, it is highly recommended to adopt a holistic approach to control. To do this, PPV control could be coresponsibility of the public and private sectors, with the public sector implementing mandatory control measures as SAG did in Chile (SAG, 1994), and the private sector collaborating via the use of certified genetic material, virus-resistant varieties, vector control, and elimination of affected plants.

The eradication of PPV has proven impossible, particularly in Chile, which is why preventive measures have been required to prevent its spread. In this respect, Muñoz (2001) suggested that the mandatory control measures of SAG have been successful in controlling the disease and preventing serious economic damage and the spread of the virus. In the last 10 years the number of positive samples from nursery mother plants taken by 
SAG has decreased from $1.63 \%$ in 1995 to $0.008 \%$ in 1999 (Muñoz, 2001). However, 20 years since PPV was detected, it seems that extensive surveys are still necessary to monitor the movement of the virus by large number samples of all stone fruit species from a large number of commercial orchards. Although regulations require nurseries to analyze mother plants for PPV, there is no systematic program for plant certification in nurseries (Müller and Mártiz, 2011). As well there is no detailed information on the susceptibility or resistance to PPV of the varieties used by producers. European countries have made significant efforts to test their own plant species against PPV to define their behavior and recommend the best stone fruit cultivars to producers (Barba et al., 2011). Extensive screening of germplasm has failed to identify sources of resistance among peach species. In contrast, resistant strains of apricot and plum have been identified. In Europe, where the spread of PPV is no longer under control, the cultivation of less susceptible or partially tolerant cultivar allows the continuation of stone fruit production. However, this practice may contribute further to PPV spreading. Under such circumstances, mineral oil treatment to control aphid vectors, which reduces but do not totally prevent PPV from spreading to young plants in nurseries, might be considered as an additional measure. The only in Chile related to cultivar reaction to PPV was done by Wong et al. (2010), who demonstrated the effective resistance of transgenic C5 plum to four Chilean isolates of the PPV-D strain.

\section{CONCLUSIONS}

Twenty years after the detection of PPV in Chile, it now seems clear that the disease cannot be eradicated despite the measures undertaken to do so. This necessarily means that in the future the fruit industry must contain and manage the disease, because of which, complementary efforts of the public and private sectors are needed to prevent the virus from spreading. This review reflects important efforts in detection, identification, distribution, and incidence of the virus in different species of stone fruit in Chile. However, there is a lack of data on epidemiological factors that would allow a better understanding of the performance of the virus under Chilean conditions. Consequently, it is necessary to develop research to accurately determine aphid vector species and their efficiency of transmission to each stone fruit species. There is some evidence of the susceptibility or resistance of our varieties, but more information is needed to make recommendations for their use by producers. As well, there is an evident need to map the areas with greater or lesser amount of viral inoculum in order to concentrate long-term eradication efforts in some areas. As well, the identification of asymptomatic plants under field conditions is necessary as part of studying the epidemiology of isolates in Chile.

\section{LITERATURE CITED}

Acuña, R. 1993. Outbreaks of Plum pox virus in Chile. European \& Mediterranean Plant Protection Organization (EPPO) Conference Plum pox virus, Bordeaux, France. 5-8 August. EPPO, Paris, France.

Adamolle, C., G. Boeglin, G. Labonne, T. Candresse, and J.B Quiot. 1994. Une souche nécrogène du plum pox potyvirus provoque un dépérissement sur certains cultivars de pêcher. EPPO Bulletin 24:721-730.

Ascui, L., and M. Alvarez. 1988. Identificación del anillado necrótico de los prunus (PNRSV) mediante ELISA. Agricultura Técnica 48:71-74

Atanosoff, D. 1932. Sharka po slivite. Edna nova virusna bolest Plum pox. A new virus disease. Annuaire de L'Universite de Sofia, Faculte D'Agronomie et de Sylviculture 9:49-70.

Auger, A.J. 1989. Tomato ringspot virus (TomRSV) associated with brownline disease on prune trees in Chile. Acta Horticulturae 235:191-204.

Barba, M., A. Hadidi, T. Candresse, and M. Cambra. 2011. Plum pox virus. p. 185-197. In Hadidi, A., M. Barba, T. Candresse, and W. Jelkmann (eds.) Virus and virus-like diseases of pome and stone fruits. APS Press/American Phytopathological Society, St. Paul, Minnesota, USA.

Cambra, M., N. Capote, A. Myrta, and G. Llácer. 2006. Plum pox virus and estimated cost associated with Sharka disease. EPPO Bulletin 32: 202-204.

Candresse, T., and M. Cambra. 2006. Causal agent of Sharka disease; historical perspective and current status of Plum pox virus strains. EPPO Bulletin 36:239-246.

Cervera, M., J. Riechman, M. Martín, and J. Garcia. 1993. 3'-terminal sequence of the plum pox virus PS and ŏ6 isolates: evidence for RNA recombination within the potyvirus group. Journal of General Virology 74:329-334.

Christov, A. 1944. Problem of Sharka diseases. Fruitgrower 8:1-2.

Dal Zoto, A., J. Ortega, J. Raigón, S. Caloggero, and D. Ducasse. 2006. First report in Argentina of Plum pox virus causing Sharka disease in Prunus. Plant Disease 90:523.

Deborré, G., W. Jelkman, and E. Maiss. 1995. Biological and molecular investigation of several plum pox virus isolates. Acta Horticulturae 386:253-262.

Dunkle, R. 1999. APHIS. Plant Protection and Quarantine 99:15

Dzhuvinov, V., S. Bozhkova, V. Milusheva, and S. Gercheva. 2007. Investigation of Plum Pox Virus in Bulgaria for the past 70 years. Bulgarian Journal of Agricultural Science 13:265-272.

Fiore, N., C. Araya, A. Zamorano, F. González, R. Mora, J. SánchezNavarro, et al. 2010. Tracking Plum pox virus in Chile throughout the year by three different methods and molecular characterization of Chilean isolates. Julius-Kühn-Archiv 427:156-161.

Hadidi, A., and L. Levy. 1994. Accurate identification of Plum pox virus and its differentiation from Asian prunus latent virus in Prunus germplasm. EPPO Bulletin 24:633-643.

Herrera, G. 1994. Detection of Sharka disease (plum pox virus) in an old stone fruit collection at Los Tilos Experimental Substation (INIA), Chile. Agricultura Técnica 54:187-191.

Herrera, G. 1996. Panorama virológico en frutales de carozo, pomáceas y vides en la zona central de Chile. Simiente 66:35-36.

Herrera, G. 1997. Enfermedades causadas por virus en frutales; panorama y perspectivas. Anuario del Campo 132-136.

Herrera, G. 2000a. Enfermedad de Sharka en Chile Plum Pox Virus, PPV. Informativo La Platina $\mathrm{N}^{\circ} 10.2 \mathrm{p}$.

Herrera, G. 2000b. Virus en viveros de frutales de carozo. Tierra Adentro 35:22-24.

Herrera, G. 2001. Enfermedades causadas por virus en frutales. Boletin Técnico INIA 52:1-65.

Herrera, G., and M. Madariaga. 2002. Incidence of Prunus necrotic ringspot virus (PNRSV), Prune dwarf virus (PDV), Tomato ringspot virus (ToRSV) and Plum pox virus (PPV) in stone fruit nurseries in the Central Zone of Chile. Agricultura Técnica $62: 38-45$ 
Herrera, G., and M. Madariaga. 2003. Natural spread of virus causing Sharka disease (Plum pox virus, $\mathrm{PPV}$ ) during three seasons in an apricot orchard. Agricultura Técnica 63:202-206.

Herrera, G., M. Rosales, and P. Hinrichsen. 1997. Detection of Sharka disease (Plum Pox Virus) in Chile. p. 87-90. Proceedings of the Middle European Meeting '96 on Plum Pox, Budapest, Hungary. 2-4 October. Plant Health and Soil Conservation Station (PHSCS), Ministry of Agriculture, Budapest, Hungary.

Herrera, G., P. Sepulveda, and M. Madariaga. 1998. Survey of Sharka disease (Plum pox virus) on stone fruit trees in Chile. Acta Horticulturae 472:393-399.

Llacer, G., L. Avinent, and A. Hermoso de Mendoza. 1992. Epidemiologia de Plum pox virus en Valencia. Acta Horticulturae 309:129-134.

Malinowski, T., M. Cambra, B. Capote, M. Zawadzka, R. Gorris, R. Scorza, and M. Ravelonandro. 2006. Field trials of plum clones transformed with the Plum pox virus coat protein (PPV-CP) gene. Plant Disease 90:2012-2018.

Millán, R. 1995. Identificación y distribución de Plum Pox virus (PPV) en duraznero (Prunus persica). 22 p. Tesis Ingeniero Agrónomo. Universidad de Concepción, Facultad de Agronomía, Chillán, Chile.

Müller, V., and J. Mártiz. 2011. La certificación hoy; ¿Cuánto nos importa la calidad de plantas? Agronomía y Forestal UC 42:28-31.

Muñoz, M. 2001. Resultados del control obligatorio y seguimiento fitosanitario de Plum pox virus (PPV) durante el periodo 19951999. X Congreso Nacional de Fitopatología, Valdivia, Chile. 1820 octubre. Simiente 71(1-2):33-73.

Muñoz, M., and M. Collao. 2006. Plum Pox Virus in Chile. Bulletin OEPP/EPPO 36:205

Németh, M. 1986. Virus, Mycoplasma and Rickecttsia diseases of fruit trees. Martinus-Nijhoff Publisher, Dordrecht, The Netherlands.

ODEPA. 2012. Cifras de presentación de la agricultura chilena. Frutales: Superficie y producción. Oficina de Estudios y Políticas Agrarias (ODEPA), Ministerio de Agricultura, Santiago, Chile. Available at http://www.odepa.cl/articulos/MostrarDetalle.action ;jsessionid=3A4A967EBCC1 A65915920BAEE953B136?idcla= 12\&idn=1737 (accessed September 2012).
Ravelonandro, M., C. Varveri, R. Delbos, and J. Dunez. 1988. Nucleotide sequence of the capsid protein gene of Plum pox virus. Journal of General Virology 69:1509-1516.

Reyes, F., N. Fiore, A. Reyes, P. Sepúlveda, V. Paredes, and H. Prieto. 2003. Biological behavior and partial molecular characterization of six Chilean isolates of Plum pox virus. Plant Disease 87:15-20.

Reyes, F., A. Reyes, P. Sepúlveda, G. Herrera, P. Hinrichsen, J. López-Moya, and H. Prieto. 2001. New insights on Plum pox virus present in Chile. Acta Horticulturae 550:135-140.

Rosales, M., P. Hinrichsen, and G. Herrera. 1996. PCR-specific detection of a Plum pox virus (PPV) isolate in Chile. Agricultura Técnica 56:89-98.

Rosales, M., P. Hinrichsen, and M.G. Herrera. 1998. Molecular characterization of Plum Pox Virus (PPV) isolated from apricots, plum and peaches in Chile. Acta Horticulturae 472:401-407.

SAG. 1994. Servicio Agrícola y Ganadero establece el control obligatorio de la plaga de los vegetales que indica en todo el territorio nacional y establece medidas de carácter obligatorio. Diario Oficial 43.843:2.

Thompson, D., M. McCann, M. McLeoid, D. Lue, M. Green, and D. James. 2001. First report of Plum pox potyvirus in Canada. Plant Disease 85:97.

Topchiika, M. 1992. Detection of Plum pox virus (PPV) in different tissues on sweet and sour cherry by ELISA. ISHS Newsletter 6:23.

Trifonov, D. 1965. Plum pox infection rate of some varieties of plums in the heavily contaminated region of Bulgaria. Plant Protection 85-88:375-378.

Wetzel, T., T. Candresse, M. Ravelonandro, and J. Dunez. 1991. A polymerase chain reaction assay adapted to Plum pox potyvirus detection. Journal of Virological Methods 33:355-365.

Wong, W., P. Barba, C. Alvarez, A. Castro, M. Acuña, P. Zamora, et al. 2010. Evaluación de la resistencia de ciruelo transgénico C5 (Prunus domestica L.) contra cuatro aislamientos chilenos de Plum pox virus a través de microinjertos. Chilean Journal of Agricultural Research 70:372-380. 